\title{
Diálogos \\ sobre a natureza \\ do teatro
}

Estes diálogos constituem uma tentativa de retomar e reexaminar temas debatidos em sala de aula, nos meus cursos de Estética Teatral e Teoria do Teatro no Departamento de Artes Cênicas da ECA. USP. Evidentemente, os nomes dos alunos não guardam nenhuma correspondência com interlocutores reais e mesmo os verdadeiros são fictícios... O autor condenou-os, pois, a um anonimato nomeado, ressalvando naturalmente, nesta anonímia, como é de boa norma acadêmica, o Professor.

\section{A TRÍADE ESSENCIAL: TEXTO, ATOR E PÚBLICO}

I

rofessor: Para que o teatro dramático exista, são necessários três elementos operativos que podemos chamar de "tríade essencial": o texto, o ator e o público. Isto é fundamental.

Com relação à definição de texto, é importante não o encarar num sentido muito estrito e tradicional, encerrando-o em cânones literário-dramáticos; deve-se tentar sempre compreender aportes novos neste campo e ver em que medida estão ou não relacionadas a formas de linguagem e estruturas de composição anteriores, analisando qual o seu efetivo grau de novidade e, sobretudo, sua pertinência ao âmbito em que pretendem atuar, porque muitas vezes o que ocorre é que o novo oculta o seu relacionamento intrínseco com os padrões textuais já estabelecidos. Determinados tipos de teatralização chegaram a ser considerados inconsistentes ou inviáveis por não atenderem a paradigmas e leis julgadas 
essenciais em termos da dramaturgia convencional. Acredito que isso tenha trazido, em reação, sobretudo em épocas mais recentes, uma descaracterização do que seja texto no teatro. De fato, o teatro não é um mero "fazer" ou um "evento" aleatório que acontece, simplesmente - não é “qualquer coisa” que é teatro. Se nós o caracterizarmos como algo que se produz a partir do momento em que se tem a intenção de fazê-lo, tal proposta-intenção será básica, mas em si não perfaz ainda o teatro. Pois este é um ser que se constitui, tem funções, expressão material, enfim, uma realização concreta e específica. Fica claro, portanto, que a intenção é o ponto de partida para o trabalho, mas como tal não basta para ser identificada como teatro.

Sob esse prisma e sendo o teatro o produto de um processo de construção, o tex to tem sido considerado como esse ponto inicial. Eassimé, mesmo quando não se respeitam os cânones do que conhecemos costumeiramente como texto dramático. A performance, por exemplo, se a tomarmos segundo as suas feições mais recentes, apresenta uma organização, utiliza expressões, palavras, recursos e desenvolvimentos que são típicos de uma textualização dramatúrgica, isto é, sempre funcionarão como um dado textual, independentemente do papel que desempenhem em sua economia dramática as sínteses plásticas em imagens e os componentes sonoros. Há, naturalmente, a questão do happening, que se coloca numa área-limite; ainda neste caso, é possível discutir se os signos emitidos não sofreriam um tipo de realização de caráter textualizante. Sem dúvida, a performance constitui-se realmente numa montagem de elementos e códigos, onde é perfeitamente possível conceber-se a existência de um “texto" ou de um “pré-texto". Evidentemente, embora desencadeado sempre por um “pretexto", o happening possui uma natureza

J. GUINSBURG é professor de Teoria do Teatro da ECA-USP e autor de, entre outros, Stanislavsky, Meierhold e Cia. (Perspectiva). 
Nesta página e

na seguinte,

personagens

da comédia

deel'arte $e m$

águas fortes de

Jacques Callot singular, dado o alto grau de indeterminação e improvisação das ações e dos actantes que o produzem. Mas toda manifestação, todo evento em que o "repetir" e o "repetirse" intervenham, isto é, nos quais se assinalem armações prévias e procedimentos reapresentados, mesmo que acolchoados pela palavra "projeto", desenvolvem-se segundo um desígnio e uma ordem referidos a alguma espécie de textualidade. Creio que, sob semelhante ótica, até os rituais mais primitivos dispõem, por seus simbolismos e sequienciamento, de um "texto" implícito, passível de leitura. É claro que, antes de tudo, cumpre discutir se efetivamente é possível denominar esses fenômenos de teatro. Tais “espetáculos" têm, por certo, elementos teatrais. Mas seria cabível dar o nome de teatro à apresentação de um prestidigitador, por exemplo? Da mesma maneira, posso estender a pergunta a outras modalidades peculiares de exibição espetacular.

Prisco: Sob este ponto de vista é possível pensar que de alguma maneira também existe algo de teatral na música. Para começar, ela possui uma escrita. E em sua apresentação, quando tocada por uma or-

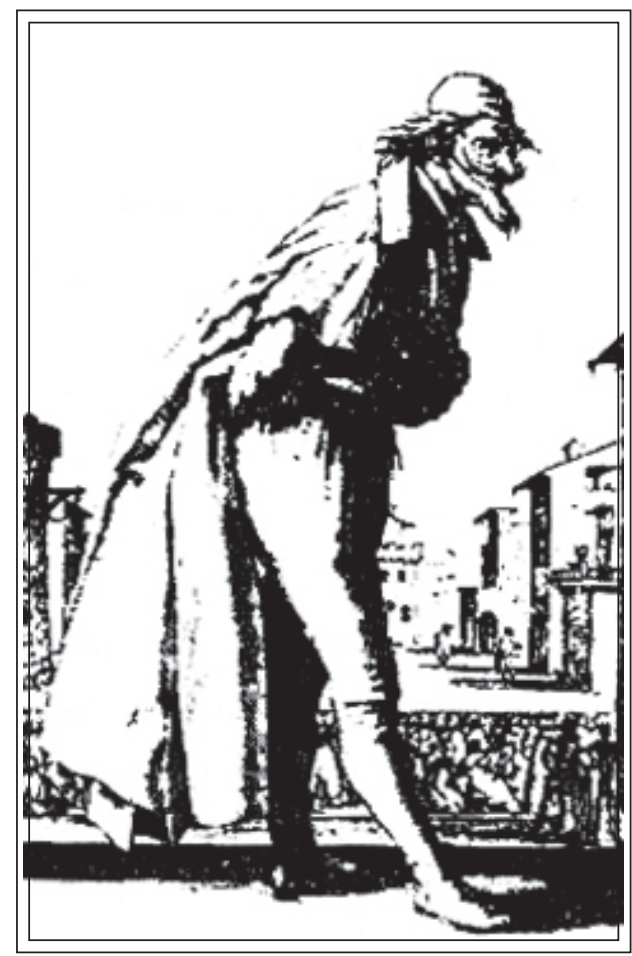

questra, há algo de "teatral", além de, é claro, tudo o que pode ser levado em consideração atualmente com respeito à atuação do músico e da questão do "musical", que, deliberadamente, utiliza-se de elementos cênicos. Acho mesmo que na execução da música existe expressão teatral. Isto se comprova pelo menos na música popular, onde o improviso tem peso teatral.

Professor: Perfeitamente, ou seja, há teatralização quando determinadas funções são ativadas. Quando um músico assume em público o papel de "músico" e pretende comunicar, além do conteúdo de sua execução, a sua característica de músico, a sua "interpretação", de fato a sua atuação adquire uma feição teatral, e é claro que quanto mais ele a acentua, mais teatralmente estará se desempenhando.

Valdir: Geralmente Arthur Moreira Lima é considerado bastante "teatral”, pelo jogo cênico que realiza ao tocar.

Professor: Sim, porque ele procura transmitir a execução com recurso a um outro meio, além do estritamente musical.

Marli: O Arrigo Barnabé também!

Valdir: É verdade, mas no caso do Arrigo isto é proposital.

Prisco: Eu concordo. Mas acho que há algo de teatral anterior a tudo isso, ao próprio fato de um músico aproveitar-se de uma postura desengonçada ao tocar, criando uma atmosfera teatral... Acredito que, mesmo que ele toque "quieto", no ato de interpretar a música já existe alguma coisa teatral, digo interpretar no sentido de tirar notas musicais, dar vida a signos.

Professor: De fato, se o executante tiver esse dom especial no seu modo de tocar estará combinando duas coisas: o elemento gestual e o básico, no caso, o musical. Pode haver na execução maior ou menor expressão "géstica”, mas a mera intenção gestual nos coloca diante do teatral, pois 
nela já reside o intuito de desempenhar o papel de “músico". É claro que este propósito não se apresenta de um modo deliberado. Mas, deliberado ou não, caracteriza-se aí um elemento teatralizante. O mágico também poderá acentuar ou não este fator. Em geral ele o faz, uma vez que o próprio objetivo de seu trabalho - o de apresentarse - inscreve-o nessa moldura e, principalmente, os atos e procedimentos a que recorra para realizar e comunicar a sua mágica. Quer dizer que os atos e os recursos necessários à operação mágica são acrescidos de um segundo sistema de signos e ações, sistema este ligado à assunção de um papel. De maneira semelhante, quando saio de casa e vou ao meu escritório, assumo uma determinada postura e adoto uma série de gestos que, eventualmente, podem ter uma certa relevância por serem específicos a um determinado espaço e momento. É claro que não podem ser definidos como gestos teatrais, mas, de outra parte, um chefe de escritório pode tomar diante de seus subordinados uma postura particular, ligada à sua condição de chefia e que talvez nada tenha a ver com o que ele sente de fato.

Vemos que também nesses casos há graus de variação: quando alguém está exaltado, pode envolver-se numa briga, mas também conter-se ou reagir friamente. Isso já confere aos gestos uma deliberação que os tornam mais próximos daquilo que chamamos teatral.

Pelo que temos visto, as finalidades dramáticas podem ser mais ou menos enfatizadas. Assim, sem dúvida, existe algo que aponta e caracteriza o elemento teatral. Se esse elemento é muito mais amplo e ocorre com maior freqüência do que comumente se supõe, não quer dizer que não haja uma especificidade-que tudo seja teatro; o que, inclusive, parece constituir o perigo de certas formas de abordagem do problema teatral. É claro que o teatro é ato, mas é um ato intencional. Um ato pode estar dotado de qualidades teatrais, mas de qualidades que tornam adjetiva, e não substantiva, a teatralidade. Desta forma, cabe ao criador teatral aproveitar as capacidades do universo teatralmente adjetivo para enriquecer a substantividade teatral. As novas leituras e reações da arte teatral procuram fazê-lo. Assim, em vez de um conjunto fechado de elementos operativos, com regras bem definidas, é possível ter-se
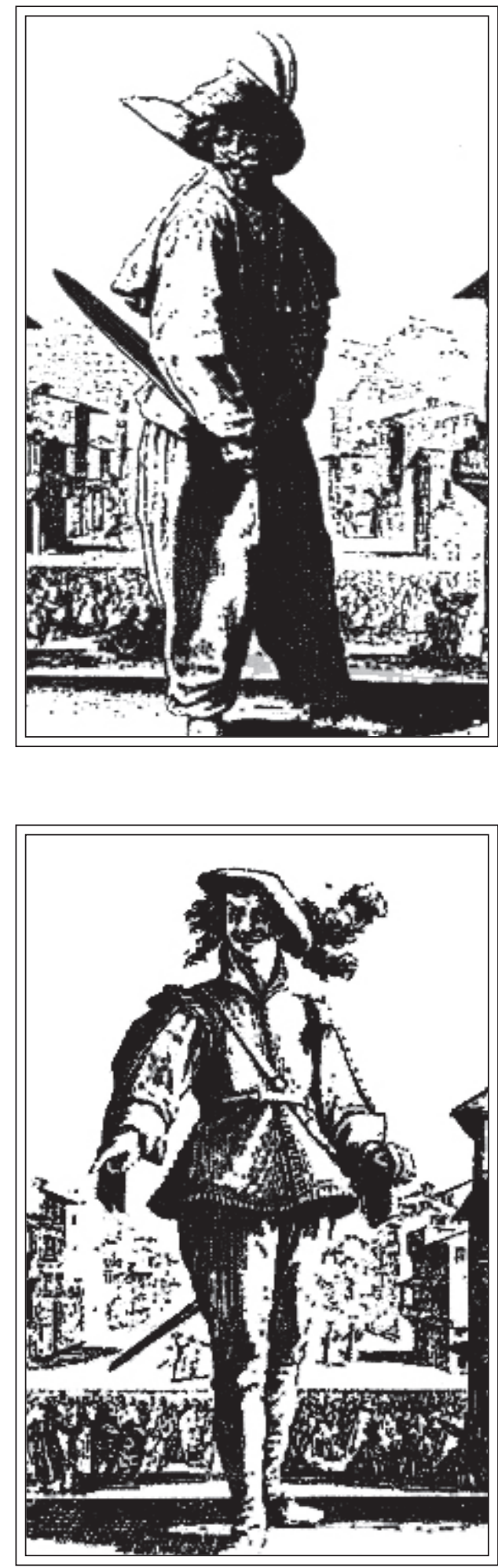
enfoques mais abertos e distintos, com igual factibilidade criativa. Se insistíssemos em ficar sempre no mesmo ponto, estaríamos limitados, nas várias acepções do termo, a imitar - esta, aliás, era a proposta de certa época, em que se imitavam as obras tidas como perfeitas, isto é, "belas", a fim de efetuar uma "aproximação" a um certo modelo tido como ideal. Apesar de pertencer ao passado, este modo de ver não deixa de ser importante também para nos ajudar a compreender o que distingue e caracteriza efetivamente o teatro, o que faz com que um conjunto de funções postas a atuar de uma certa maneira se tornem, ou não, teatrais. Assim sendo, quando encontramos elementos teatrais numa série de coisaseventos em toda a nossa vida, isso não é de surpreender. Seria surpreendente se o teatro existisse sem que tais coisas existissem de fato na vida: o teatro pertenceria a uma esfera inteiramente extraterrena. Temos, sim, que nos surpreender com o momento em que o fenômeno passa a ser definidamente teatral, senão poderíamos dizer simplesmente que "tudo é tudo".

\section{II}

Professor: A intenção de atuar e a assunção da máscara instauram, necessariamente, o espaço teatral - porque o corpo do sujeito dessas ações é um corpo no espaço. Assim, no momento em que alguém assume um papel, estabelece um espaço que, já pela intenção do agente, é cênico. Se este é adequado ou não, se está ou não preparado para receber o ator e seu desempenho, isto não importa no caso, pois não interfere no fato de que o atuante, com a sua corporeidade, instaura de um modo automático o espaço da ação.

Marli: Portanto, isto acontece sobre o tablado?

Professor: Não apenas nele, pode acontecer até aqui e agora. Se em determinado momento me der na veneta e ficar com vontade de fazer uma brincadeira com vocês, deixando de lado o acordo tácito existente entre nós, segundo o qual o fato de eu ser professor dispensa maiores reafirmações sígnicas, e eu resolver ressaltar a minha figura com intuito teatral, começando a "interpretar" o meu papel, estabelecer-se-á imediatamente uma linha entre nós, pela qual eu me constituirei em intérprete-em ator-e vocês, se entrarem no jogo teatral comigo, se constituirão em platéia; assim, o espaço dramático definido pela divisória entre ator e público não é a linha estabelecida materialmente em um teatro convencional, ou uma construção ou um espaço qualquer, porém aquela que se instaura num fenômeno dado aqui e agora, numa relação ao vivo. Eu me constituo em ator, porque o meu ato adquire uma característica pela qual vocês me constituem em ator, através de uma deliberação minha que é aceita e/ou compreendida por vocês. Mesmo quando se diz a uma pessoa: "Fulano, deixe de fazer teatro", é claro que houve de sua parte algum modo de atuação intencional, pois se captou no gesto dele (ou se lhe atribuiu) algo pelo qual esta pessoa assumiu um certo papel teatral; neste caso, todavia, essa deliberação pode não ter sido total ou inteiramente consciente, mas simplesmente um gesto que teve um "recorte" especial, um "relevo" qualquer, que se destacou no fluxo dos outros gestos e das palavras proferidas.

Desta forma, vemos que até com a ausência de qualquer área de jogo teatral preestabelecida, para não falar de um palco em grau zero cenográfico ou de um desempenho despido de toda parafernália da caracterização, pode ocorrer a manifestação do teatro. Daí por que não há impedimento em realizá-lo em praça pública, na rua ou em qualquer sítio, como ninguém ignora. Nestas condições, não é verdade que se possa fazer teatro apenas num lugar especialmente preparado, embora muitas vezes um local assim propicie condições bem mais adequadas para se alcançarem os objetivos que a arte dramática se propõe.

Marli: O senhor já se referiu algumas vezes à idéia de um "reflexo", ou seja, que só 
existe o ator quando existe a platéia. Então, o ator existe sem personagens, mas não existe sem público?

Professor: Trata-se de uma relação constituinte e não creio que se possa considerá-la um puro "reflexo". Não há nenhum automatismo instituidor da situação actancial. Assim, em sua identidade civil, é evidente que fulano, ator por profissão, sempre existe como tal enquanto lhe aprouver e viver, incorpore ou não uma personagem. Em sua qualidade dramática, porém, essa condição começa a revesti-lo desde o momento em que surge em seu íntimo a intenção de desenvolver alguma ação de natureza teatral, pois a mera intenção já envolve muita coisa; envolve, no mínimo, o projeto de suspender, por pouco que seja, o fluxo do aparecer civil e corriqueiro de seu ser e produzir com ele, deliberadamente, por invocação, duplicação e invenção, signos verbais e gestuais atualizados aqui e agora que o façam parecer ser, qualquer que seja o objeto de sua intenção, inclusive ele mesmo. É claro que este seu propósito só se consubstanciará efetivamente na representação, cujas ações constituintes o instituirão como ator perante alguém que o esteja vendo e perante si próprio, uma vez que de algum modo não pode deixar de ver-se.

Por outro lado, isso corresponde ao fato de que o executante só é ator na medida em que é ao mesmo tempo espectador (a contrapartida também é verdadeira, como se verá), estando como tal não apenas fora, mas também dentro dele. Pois, para que possa atuar, realizando atos intencionais de execução, precisa concomitantemente, em seu agir, imaginar (vale falar, representare projetar), entender e administrar o que “performa”, ou seja, envolver-se e distanciar-se, no mesmo lance, no jogo de seus atos. Quer dizer, o intérprete necessita, com alguma vista ou vislumbre interior, "vêlos", "representá-los" e, com este viés, "refleti-los".

Como consequiência, cabe inferir que o crítico também está, de uma certa maneira, presente no ator. Pois o que é o crítico se- não um espectador diferenciado, supostamente especializado, cuja distinção, em face dos demais, decorreria não só do exercício de uma certa atividade, mas também do fato de dispor de instrumentos e conhecimentos requeridos para apreciar e julgar a obra teatral? Por outro lado, o seu modo de fazêlo, de conhecer e avaliar o seu objeto, provém de uma recepção e uma análise que, por sua natureza crítica, demanda uma certa distância, por mais envolvido que esteja, um ângulo de "visão" objetivante. Nesse sentido, o ator está condenado, em princípio, a sofrer algum prejuízo crítico, na medida em que pode imaginar-se, mas não pode contemplar-se totalmente. Ainda assim, é indubitável que ele se mantém consciente daquilo que faz enquanto o faz e do que daí resulta, porquanto o seu próprio esquema corporal o leva a percepções que lhe permitem coordenar e dirigir seus gestos, assim como ter a noção de que "isto está correto" e "aquilo está errado", por exemplo.

\section{III}

Professor: Como remate de nossa indagação sobre o estatuto do ator e das condições em que ele é instituído em sua função teatral, cabe dizer, pois, como consta de meu trabalho sobre $O$ Teatro no Gesto, que o comediante, na medida em que concretiza a metamorfose do ator em personagem, incorpora de certa forma, se não a totalidade, no mínimo partes vitais do trabalho do diretor, sendo possível ver, no palco dramático, a interpretação do ator como órgão principal da realização do encenador. Assim, ainda que este deva lançar mão também de outros actantes cênicos para materializar sua arte encenante em obra representada, a máscara encarnada no intérprete, produto de sua relação com o papel, converte-se no elemento central do teatro, aquele que o diferencia de outras modalidades de comunicação artística e intelectual. A segunda relação importante no espetáculo é a do ator com o público. 
Noêmia: "Máscara encarnada" possui o mesmo sentido que "personagem"?

Professor: Em média, sim. Mas é claro que, no teatro especificamente, sem se falar da literatura em geral e da dupla leitura do texto dramático, isto é, a literária e a teatral, o conceito "personagem" pode ser objeto de uma discussão por si. De qualquer maneira, no nosso caso sempre supõe a presença de uma persona, ou seja, de uma máscara e de um corpo que vai assumi-la e ao qual irá revestir como "outro” em relação ao "eu” do ator, por delegação estética. Em rituais, sem propósito estético-teatral, o seu potencial artístico não é explorado com tal finalidade, ao contrário do que ocorre no palco. Eneste sentido, a concreção de uma máscara em cena importa na de uma personagem, com suas condições de contorno, isto é, na materialização de um ser ficcional deliberadamente criado para desempenhar tal função dramática, que se encarna ao vivo, sem mediação de um veículo "frio", como sucede no cinema e na $\mathrm{TV}$, no corpo do ator e corporifica em ato o fenômeno teatral.

\section{IV}

Professor: Tendo examinado o texto e o intérprete quanto ao seu modo de ser e o de suas relações, podemos voltar-nos agora para o público em face do teatro em ato. É uma situação que se define por um relacionamento peculiar, pois se trata quase de um "comércio" ao vivo.

Noêmia: Mas tal relação pode ou não se estabelecer...

Professor: De fato, embora ao vivo, ela pode ser mais ou menos ativa. É claro que a passividade total inexiste. Ainda que algum espectador na platéia esteja pensando em outra coisa, ele está presente ao espetáculo e isso conta obrigatoriamente na economia não só da recepção como, igualmente, da emissão da representação, ou seja, da criação incorporadora que está em proces- samento no tablado. É fato conhecido que sua presença influi na ação do intérprete e pode até perturbá-la, tanto em virtude de eventuais reações coletivas quanto de uma dinâmica particular que venha a desencadear-se entre o comediante e alguém da platéia. Assim, se o ator estiver representando e um espectador agir de forma a atrapalhá-lo, o intérprete poderá deixar cair a máscara, sair de seu papel e responder civilmente... partindo para a briga, como já se viu...

Marli: Mas, com respeito ao ator, anteriormente a esta reação emotiva, a sua simples presença também já ocupou um espaço em cena...

Professor: É claro. A sua simples presença estabelece uma relação dele consigo mesmo, de sua pessoa física com um possível desempenho, isto é, uma pessoa ficcional, uma persona. É uma virtualidade sua, inerente à sua qualidade de ator, que se apresenta como tal e que o trabalho de atuação, à medida que for se presentificando na representação, poderá ou, antes, deverá converter em realidade dramática. Desde o início, portanto, haja ou não público na platéia ou alguém constituído em espectador por uma situação momentânea ou casual, a presença de um comediante no palco, mesmo sem uma execução interpretativa, mas sob fiança da promessa de intenção, inaugura um fato comunicacional de natureza teatral. Esse processo constitutivo da relação, focalizado na figura do ator individualmente, não muda de caráter com o número de desempenhantes, embora se torne, sem dúvida, mais complexo, e a dinâmica do fenômeno em grupo pode levar até ao esbatimento ou anulação de sua percepção individualizada.

Norma: Quando coloquei a questão, eu queria ir um pouco mais além. A meu ver, há dois tipos de espectador: aquele que consegue decodificar os elementos que estão no palco, que consegue não apenas assimilar, mas também avaliar aquilo que está 
sendo apresentado, e há o espectador que em determinado momento é apenas um observador, que parece não apreender o significado de cada elemento. Isto também se constitui numa relação?

Professor: Sim, porque esta também é uma forma de relacionar-se com o que está acontecendo no palco. A caracterização de atitude que você propôs é correta grosso modo, mas em um e outro caso o ato teatral está em pleno processamento. Veja bem, estamos examinando aqui apenas algumas inter-relações básicas que se estabelecem nesta ocorrência, que poderá suscitar, sem dúvida, diferentes graus de envolvimento, desde um máximo até o zero de uma escala, por assim dizer. Porém, inclusive em seu nível mínimo, a dinâmica desta inter-relação, fundada sempre pela co-presença ator/espectador -, não é suprimida e, mesmo que assuma uma eventual aparência de passividade, ela se encontra na verdade em "ponto morto", num momento dialético de passagem.

De outra parte, sabe-se que, no comércio do ator com o público, a indiferença, o desinteresse, a participação, o embevecimento, etc. são de um para o outro comunicados imediatamente, fluem de modo subliminar. $\mathrm{O}$ fenômeno, é claro, não se restringe ao teatro. Até eu, no lugar e na condição em que me encontro agora, olhando para vocês - numa situação não-teatral - sinto de pronto, sem deliberação prévia de minha parte, o grau de envolvimento de vocês com aquilo que estou dizendo. Imaginem o ator no palco... muito mais! Ele está aí tão “aceso” na recepção quanto na emissão.

Valdir: Isso fica bem perceptível quando o público varia, por exemplo, quanto à classe social. As reações são bastante diferenciadas.

Professor: De fato, e a variação não se esgota em seu aspecto sociológico. Repare que não é só o intérprete que desempenha bem ou mal, com adequação ou inadequação. A platéia também. Isto pode parecer paradoxal, uma vez que o papel atribuído ao espectador segundo o modo habitual de se conceber a operação teatral é puramente passivo. Supõe-se que, ao se predispor a assistir a uma peça, o público deva não mais do que localizar-se corporalmente em dado ponto do espaço onde o “teatro" terá lugar e, nele, comportar-se de um certo modo, seja na condição grupal seja na individual, a fim de poder dar conta de um compromisso operacional tacitamente assumido à entrada, que é o de pactuar, numa postura de entrega, com a atualização de um jogo de faz-de-conta. A presença do espectador é vista, portanto, como a de uma presença passivamente à disposição do que a emissão cênica tem a lhe oferecer. Ele conta muito como um observador, um apreciador, que acolhe ou não o que lhe é endereçado e nada mais. Nisto se resume, segundo este tipo de análise, o seu processo de recepção da obra. Visto como totalmente acabado ao ser desencadeado em sua origem, o complexo fenômeno pelo qual se torna realidade e "forma" interior do receptor e se constitui em objeto para ele, não é levado em maior conta estética. É como se ocorresse "no vazio" ou se as imagens e as cargas emotivas, para não falar nas idéias, se limitassem a estampar-se numa cena amorfa. No entanto, se o espectador não puser em andamento a sua aparelhagem não só de percepção e decodificação, mas de reatuação na cena de seu imaginário, com a animação de sua sensibilidade e a organização de sua consciência, istoé, se deixar de projetar, enformar e falar interiormente, se não se tornar locutor daquela linguagem, o diálogo constitutivo inexistirá para ele e a peça tampouco. Vale dizer que, no plano individual e, por seu intermédio e da relação intersubjetiva pela qual se estabelece o plano coletivo, o público também “interpreta” e o seu desempenho poderá ser de boa ou má qualidade, por sua vez. Mas não se trata de pura e simples resposta automática ao que está assistindo. A melhor representação nem sempre engajará uma atuação adequada do espectador ao perfazer os atos de recepção. E é possível que sua falha, dependendo de como ela se manifestar e do efeito que exercer sobre 
outros membros da platéia, seja de molde a desestabilizar o espetáculo todo, sem que implique juízo de valor a seu respeito.

Isabel: E se implicar, como no caso do crítico?

Professor: Não creio que este goze de algum estatuto especial no modo de receber a obra teatral. Ainda que sua missão precípua seja precisamente a de formular julgamentos tão objetivos quanto possível sobre a qualidade e o valor artístico dos espetáculos a ele apresentados, não tem como eximir-se do processo acima descrito, justamente porque também é um espectador. Como tal, não importando o grau de instrumentação de que disponha para exercer a sua função de crítico, antes de mais nada terá de executar, como todo o público, as operações que lhe permitam a recepção da obra. Trata-se do primeiro nível de sua apropriação do objeto, mesmo que se lhe mescle toda sorte de intervenções intelectuais e de ajuizamentos. Contudo, é somente no que se poderia denominar de segundo nível, o qual já estava implicado no primeiro, que a apreciação crítica se colocará plenamente em plano específico. Ora, assim sendo, sua análise e suas conclusões estarão também penhoradas ao exercício de desempenho pelo qual a obra dramática se realiza no espírito do espectador que é o crítico.

\section{DUAS FUNÇ̃̃ES NECESSÁRIAS: A CONCREÇÃO MIMÉTICA E A ARTICULAÇÃO SIGNIFICATIVA}

Professor: Na constituição do que é apresentado na cena teatral, o trabalho de invenção, captação e concretização de figuras, relações e significações, explícitas ou implícitas, nas falas, no tema, no texto ou no discurso, e seja qual for a natureza, a forma e o estilo de expressão pretendidos, fundamenta-se no corpo do ator. Trata-se de uma elaboração nele centrada e a partir dele orientada, mas não no sentido estrito da simples replicação ou reprodução. Ela pode ir muito longe na concreção do abstrato como idéia e forma.

Carmen: $O$ senhor poderia dar um exemplo para que se possa entender melhor o que vem a ser essa concreção do abstrato?

Professor: Vou experimentar. Por exemplo: alguém quer representar, digamos, uma dança de corpos e figuras geométricos ou de notas musicais. O que ocorrerá, na verdade, numa ação desse feitio? Quaisquer que sejam os elementos, os movimentos, os recursos plásticos, sonoros e luminosos mobilizados para configurar diretamente a proposta e sugeri-la indiretamente, uma coisa é certa - ela terá de ser concretizada pelos bailarinos ou atores. Somente a partir daquilo que eles fizerem, isto é, “performarem”, poderá corporificar-se no palco a outra corporeidade, que não é a deles, mas, sim, a de uma idéia cuja realidade objetiva é abstrata, e que, no entanto, deverá de algum modo, sensível mesmo que ilusório, ser recebida como se fosse concretamente corporal, ou seja, "fisicalizada" no corpo de seus executantes. Este fenômeno é mesmo extensivo a outras artes de representação, como o da tela dos desenhos animados que projeta, por delegação imaginativa de seus criadores e com ajuda de meios técnicos, a movimentação de animais e objetos, às vezes altamente abstratos, cujo esquematismo não impede que sejam vistos como se dotados de gestual humano, embora o corpo vivo do ator esteja ausente.

Marcos: Agora é que o concreto ficou abstrato, para mim. Não dá para o senhor chegar mais concretamente no abstrato?...

Professor: Posso tentar. Se eu tiver sorte, como Newton, e uma maçã bater na minha cabeça... Vocês já devem ter visto algum espetáculo de balé ou teatro onde se apre- 

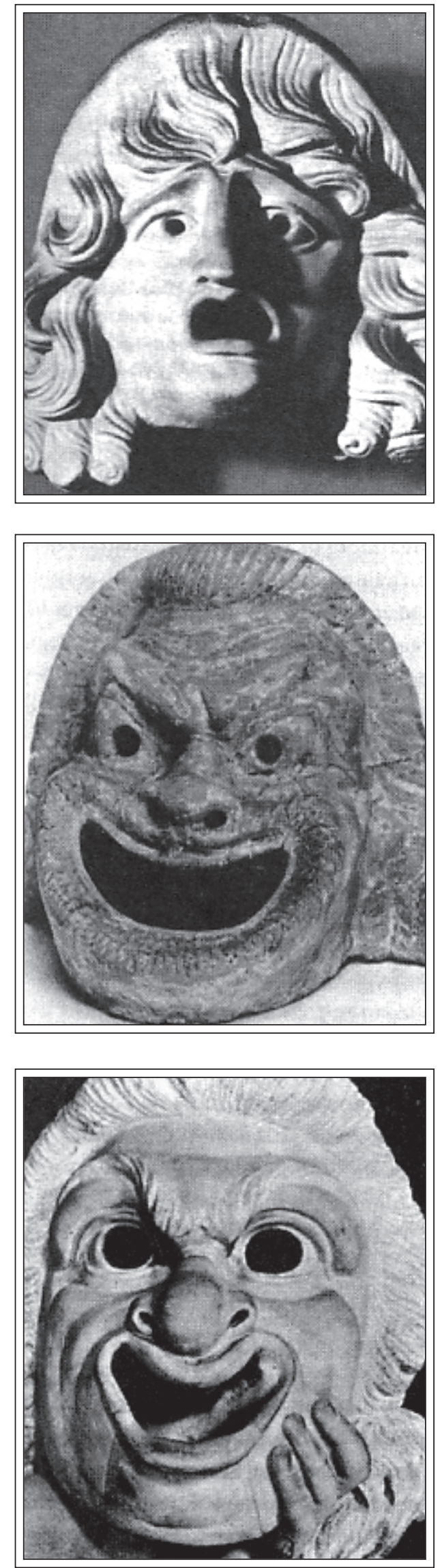

sentam coisas bastante desnaturadas a fim de causar efeitos que lhes pareçam fugir da experiência corriqueira. Porém, no fundo da desnaturação encontrar-se-á sempre um dado natural.

William: é o caso do teatro do absurdo, que utiliza uma linguagem extremamente realista como base.

Professor: Ele se torna absurdo por colocar em xeque fatos da realidade tal como ela nos é dada.

William: Só que colocando isso de uma forma completamente real.

Professor: Mas não é somente em função do choque e do contraste, geradores do grotesco, que ocorre tal presença. É possível constatá-la também quando a visada da obra artística é de caráter integrativo e harmônico. Lembro-me que esse fato chamou minha atenção durante uma apresentação de um grupo de danças modernas, o do Nikolai. Em quase todos os números a coreografia se caracterizava por seu propósito conceitual. Como se quisessem abstraíla pelo movimento, a forma corporal dos artistas sumia quase por completo. No entanto, aquelas conformações aparentemente distanciadas, que ora apareciam ora desapareciam, movimentavam-se, por certo, segundo a organização do corpo humano, e só alcançavam sentido em relação a essa organização. Assim, numa das seqüências do balé, assistia-se ao solo de um braço que se desempenhava com inteira autonomia e de repente punha-se a andar sozinho como se as demais partes do corpo do intérprete não existissem, obliteradas como estavam por hábeis efeitos, entre eles os de luz. Mas, ainda assim, os seus gestos e movimentos só se comunicavam com o espectador à medida que ele os decodificava em relação a um corpo dotado de membros e às possibilidades de seu subjacente repertório de ações.

Márcio: Quanto à realização significativa, seria ela a resultante direta da concreção mimética ou de um momento específico do 
trabalho de construção do papel?

Professor: São dois momentos interdependentes, creio eu. O primeiro é o que acabamos de discutir. Este é o ponto de encaixe a partir do qual se inicia a tradução para a linguagem corporal e, engrenadocom ela imediata e necessariamente (mesmo que do ponto de vista analítico se possa distinguir um momento do outro), o concomitante processo de preenchimento sígnico e irradiação significante - o qual adquire aceleração vertiginosa se operado também pela ação verbal, embora não lhe seja adstrito da idéia, tema, motivo, esquema, situação e personagem cenificados.

Márcio: O senhor parece que deu um salto, da análise das funções para a síntese do resultado.

Professor: Você tem razão, mas não se esqueça que estamos tentando discernir não tanto o mecanismo de produção, como o produto final integrado, isto é, a resultante da operação pela qual se constituem os componentes e o conjunto totalizado da obra artística que é o espetáculo teatral ou o de outro gênero cênico. (Alguns bocejos $e$ outros tantos olhares sonados são salvos de seu penar pelo toque redentor da campainha do intervalo. Após as generalizadas contorções e alongamento do espreguiçar-se discente, a sala se esvazia como que por encanto, tornando irresistivel a sugestão para que o docente vá também tomar o seu cafezinho...)

\section{II}

Professor: Vamos retomar a nossa discussão sob um ângulo um pouco diferente, já que agora estamos todos com os neurônios academicamente ativados pela beberagem nacional... Como observei, a concreção mimética, a assunção corporal, é indispensável para que o tipo de ilusão peculiar à cena possa ser criado e apreendido em sua especificidade artística. No teatro, mais do que em qualquer outra arte, a própria pre- sença do corpo do ator produz uma comunicação muito mais forte em dados miméticos. Quando digo "apreendido em sua especificidade artística" quero dizer simplesmente que, sem as fontes fornecidas pelas similitudes, pelas analogias, pelas leituras que podem ser feitas estabelecendo pontos de contato e relacionamento, referenciando esse dado real no tablado, pela reprojeção de esquemas significativos, não poderia operar-se na platéia a sua percepção imediata. E a ficção teatral tem de ser percebida imediatamente sob a forma de representação, ou seja, de re-apresentação. Pois, o que é essa re-presentação, senão re-presentificar, tornar presentes por atos intencionais e formais de criação, quer dizer, por delegação estética, figuras, imagens, sentimentos, relações e elementos que constituem os seus objetos, reatualizá-los artificialmente por uma assunção corporal, uma concreção mimética, na corporeidade viva do intérprete? Eis um lado da questão. O outro, que está nele embutido, é que no ato teatral a representificação é ao mesmo tempo pura presentificação. Cada ato teatral é intencional, com vistas a um fim, mas, concomitantemente, um ato original e, nesse sentido, um ato de criação, único, inexistente anteriormente, praticado aqui e agora. Alguma dúvida quanto ao caminho que tentei traçar da representação à presentificação?

Raquel: A representificação seria algo na linha de Gordon Craig? Seria mais ou menos o que ele pregou?

Professor: Seria se fosse possível juntarlhe Stanislávski, fazer uma combinatória dos dois, uma síntese, que tentada na famosa encenação do Hamlet no Teatro de Arte de Moscou, mostrou-se inviável, na teoria e na prática. Mas isso não quer dizer que, na realidade da representação, não compareçam elementos que correspondem às posições de um e de outro, atos de formalização e vivência por eles maximizados na sua busca do absoluto na criação teatral. Mas nós, em nossa indagação sobre a operação geradora da ficção 
dramática, ou seja, do real ilusório no palco, não estamos debatendo suas diferentes concepções. Num plano menos específico, sob o ângulo histórico e estilístico, trata-se aqui de efetuar uma leitura tópica do fazer teatro. Assim, retomando a nossa questão, o projeto do diretor é sempre mais o da representação que presentifica e o do ator é sobretudo o da presentificação que representa. (O professor já está quase nocaute e, por entre os volteios de seu discurso, começando a preocupar-se com os caminhos a seguir para evitar o congestionamento à saída da Cidade Universitária-e um rápido olhar sobre o grupo ofaz sentir intimamente que a classe toda pensa como ele. Mas...)

\section{III}

Sérgio: Sei que a aula está no fim... Mas sem querer atrasar os colegas, e já que o professor presentificou tudo a que tinha direito... eu gostaria de saber se a abordagem feita não resulta numa "ausentificação" do trabalho do diretor?

Professor: Fico feliz porque agora tenho certeza de que você estava presente e não ausente. No entanto, devo lembrá-lo que assinalei repetidas vezes a reserva de domínio do trabalho do encenador. Para contentá-lo e esclarecer os pontos que porventura continuaram em aberto para vocês, vamos examinar um pouco mais, e mais de perto, a questão. Parece-me que ninguém poderia pôr em xeque a imprescindível intervenção do diretor na concepção e na montagem de um espetáculo teatral, sobretudo na cena moderna. Eu diria até, sob uma forma ou outra, mesmo quando não explícita e com uma denominação não registrada, que ela sempre existiu. Por exemplo, no "teatrão" tudo se organizava à volta do primeiro ator ou atriz, que muitas vezes era o dono e empresário da companhia, e o ensaiador, como uma espécie de seu delegado, dispunha outros atores e figurantes tendo em vista essa linha diretriz. É possível dizer, pois, que, grosso modo, havia um centro gravitacional, emissor de volições e disposições, a polarizar uma direção e a fazer suas vezes na concepção e realização da peça. Sob o mesmo aspecto, considere-se um caso ainda mais simples, como seria o de um grupo ensaiando um espetáculo sem uma orientação escolhida e um orientador definido. Pode ocorrer, como é da experiência de todo ator, que, no curso desse trabalho "solto" nessa primeira instância, um dos contracenantes se imponha a certa altura, por sua força interpretativa e/ ou carisma, agrupando psicológica e cenicamente em torno de si a performance da trupe, e dando, portanto, à cena ou à peça toda, a inflexão nascida de sua maneira de atuar e de seu modo individual de coar os elementos da obra. Entretanto, não quero contornar a questão proposta pelo Sérgio e ficar numa resposta indireta. Volto, pois, ao prefixo re, o qual precede o conjunto da atividade por mim caracterizada há pouco, inclusive na parte que toca ao ator. A mencionada partícula é sem dúvida a referência sígnica que melhor aponta a função e a necessidade da operação diretorial. Porquanto, em combinação com o labor explícito de um metteur en scène, ela está presente no conjunto de elementos, recursos, ações e expressões, de que o ato interpretativo e, por decorrência, o ator em sua metamorfose cênica, na assunção da persona, terá de valer-se para levar a efeito seu desempenho e dar-lhe o devido sentido e premeditado alcance dinâmicoartístico nas imagens e emoções produzidas no jogo das personagens, conflitos e situações. Mas o espetáculo requer muito mais. E é lícito afirmar que, do projeto de direção, que poderá abranger os mínimos pormenores e os máximos significados de tudo o que se encontra e age em cena, provém a totalidade daquilo que o espetáculo pode transmitir ou transmite como presentificação teatral... (Sentindo a ameaça que se desenhava na sentença não concluída do professor e na possibilidade de Sérgio querer ir a fundo no assunto, a classe não teve dúvida: como que por efeito de uma mágica, sumiu instantaneamente no corredor.) 